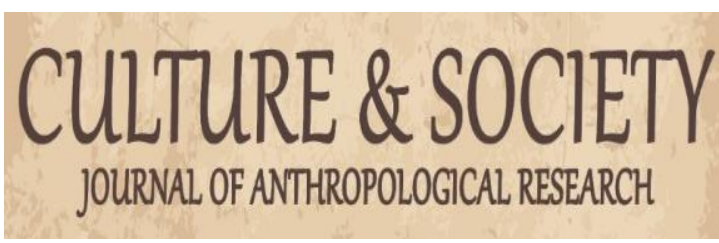

Culture \& Society: Journal of Anthropological Research

VOL. 1 NO. 3 MARET 2020

http://culture.ppi.unp.ac.id

Email: culture@ppj.unp.ac.id

ISSN: 2686-343X (E-ISSN) 2686-3421 (P-ISSN)

DOI: https://doi.org/10.24036/csjar.v1i3.36

\title{
Lauak Baniek: Kearifan Lokal Masyarakat Nagari Sungai Durian dalam Pemanfaatan Sumberdaya Lokal Berkontribusi dalam Pembangunan Nagari
}

\author{
Rian Fauzi ${ }^{1}$, Erianjoni Erianjoni $i^{2}$ Erda Fitriani ${ }^{3}$ \\ ${ }^{1,2,3}$ Universitas Negeri Padang \\ E-mail: riany150@gmail.com
}

\begin{abstract}
Abstrak
Artikel ini membahas mengenai lauak baniek di Nagari Sungai Durian Kabupaten Padang Pariaman.Lauak baniek merupakan bentuk pelestarian ikan secara tradisional oleh masyarakat nagari, yang tujuannya digunakan untuk pembangunan nagari.Tujuan penelitian ini adalah untuk mendeskripsikan kearifan lokal lauak baniek sertakontribusinya dalam pembangunan nagari.Penelitian ini dianalisis denganteori modernisasi perspektif baru yang dikembangkan oleh Michael R. Dove.Penelitian ini merupakan pendekatan kualitatif dengan tipe penelitian etnografi. Pemilihan informan dilakukan dengan teknik purposive sampling dengan jumlah informan 22 orang. Pengumpulan data dilakukan dengan observasi partisipasi dan wawancara mendalam.Data yang diperoleh dianalisis dengan mengacu pada model analisis James P Spradley. Hasil penelitian menunjukan bahwa pengelolaan lauak baniek memiliki nilai-nilai yang arif terhadap pelestarian ikan, sungai dan juga memiliki nilai kerja sama serta wujud persatuan masyarakat. Lauak baniek ternyata berkontribusi bagi pembangunan Nagari seperti pembangunan tempat ibadah, kegiatan kepemudaan, sarana serta perekonomian masyarakat.

Kata kunci: Lauak baniek, Kearifan Lokal, Pembangunan
\end{abstract}

\section{Abstract}

This article discusses lauak baniek in Nagari Sungai Durian Padang Pariaman District. Lauak baniek is a traditional form of fish preservation by the nagari community, whose purpose is used for the development of nagari. The purpose of this research is to describe local wisdom of lauak baniek and its contribution in nagari development. This study was analyzed with a newly developed perspective modernization theory developed by Michael $R$. Dove. This research is a qualitative approach with type of ethnographic research. The selection of informants was done by purposive sampling technique with 22 informants. Data collection is done by participant observation and in-depth interview. The data obtained were analyzed with reference to the James P Spradley analysis model. The results showed that the management of lauak baniek has wise values for the preservation of fish, river and also has value of cooperation and form of community unity. Lauak baniek apparently contributed to the development of Nagari such as the construction of places of worship, youth activities, facilities and the economy of the community.

Keywords: Lauak baniek, Local Wisdom, Development

\begin{tabular}{l|l|l} 
Received: March 10, 2020 & Revised: March 17, 2020 & Published: March 18, 2020
\end{tabular}

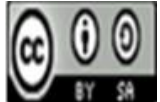

Culture \& Society: Journal of Anthropological Research Vol. 1, No. 3, Th. 2020 


\section{Pendahuluan}

Lauak Baniekmerupakan salah satu aturan yang dimiliki oleh masyarakat Desa Sungai Durian di Kabupaten Padang Pariaman dalam pemeliharaan ikan yang ada di sungai.Ikan yang ada di sungai secara sepakat masyarakat melarang untuk menangkap atau memancing ikan tersebut.LauakBaniek berasal dari dua suku kata yaitu "Lauak" artinya "ikan" dan "Baniek" artinya "berniat", sehingga secara sederhana dapat diartikan bahwa Lauak Baniek adalah ikan yang diniatkan untuk suatu tujuan. Ikan yang dilarang ditangkap, tidak untuk selamanya dilarang, ikan diperbolehkan ditangkap apabila telah sesuai dengan waktu yang telah ditentukan berdasarkan kesepakatan para pemuka adat setempat, dan biasanya ikan baru boleh ditangkap setelah jangka waktu yang telah ditetapkan.

Asal usul Lauak baniek ini memiliki dua versi cerita, pertama pada tahun 1960-an yang lalu masyarakat Sungai Durian melakukan pembangunan mesjid Sungai Durian, namun pada pertengahan pembangunan terjadi kekurangan dana pada saat pembangunan mesjid Sugai Durian. Untuk mengatasi masalah tersebut masyarakat Sungai Durian melakukan musyawarah yang dihadiri oleh para pemuka masyarakat seperti; ninik mamak, alim ulama, para pemuda serta anggota masyarakat. Dari hasil musyawarah itu timbul ide untuk membuat Ikan larangan yang dikenal dengan lauk baniak (ikan berniat). Nama lauak baniak ini dikarenakan ikan ini diniatkan untuk pembangunan mesjid, maka tidak boleh diambil oleh anggota masyarakat untuk kepentingan sehari-hari.

Pendapat yang kedua, latar belakang lauak baniek ini karena maraknya penangkap ikan di sungai tanpa memperhatiakan kelestarian ikan yang ditangkap, antara lain menggunakan racun ikan dan menggunakan sengatan listrik, sehingga ikan-ikan di sungai tidak lagi dapat berkembang karena dengan menggunakan cara yang demikian dapat mengganggu ekosistem sungai termasuk kelestarian ikan, sehingga muncul sebuah ide untuk melestarikan ikan dengan cara lauak baniek atau secara bersama berniat untuk tidak menangkap ikan.

Lauak baniek ini juga memiliki periode yang ditandai dengan ritual yang dipimpin oleh khatib Nagaridan labai nagari. Ritual penutupan ditandai dengan dilarangnya untuk menangkap ikan di sungai, kemudian ritual pembukaan ditandai dengan diperbolehkannya untuk menangkap ikan. Adapun ritual yang dilakukan untuk memulai lauak baniek ini yaitu ritual yang dilakukan di mesjid dengan kesepakatan pemuka masyarakat seperti;ninik mamak, alim ulama, datuak-datuak dan pemudasetempatserta unsur pemimpin formal seperti: wali nagari, wali korong dan anggota masyarakat lain untuk menentukan dimana tempat lauk baniek, sangsi pelanggaran dan jangka waktu lauk baniak. Setelah adanya kesepakatan maka dilanjutkan dengan pembacaan niat bersama yang dipimpin oleh khatib nagari danlabai nagari.Setelah acara di mesjid upacara dilanjutkan dengan pembacaan do'a diiringi pembakaran kemeyan di atas sabuik karambi atau sabut kelapa dan menghanyutkan kemeyan yang dibakar di atas sabut kelapa.Ritual berakhir setelah pemasangan bendera putih (kain kafan) sebagai tanda ikan baniek ditutup dan menandakan wilayah yang dilarang untuk memancing. Dan selanjutnya akan diumumkan di masjid terdekat bahwa ikan telah dilarang untuk ditangkap. Lokasi Lauk baniak di Nagari Sungai Durian berada pada empat Lokasi yang berada. Pertama, berada pada aliran Sungai Mangor yang terletak diantara Korong Sungai Durian dan Korong Sijangek, sehingga pengelolaannya diberikan kepada kedua korong. Lokasi yang kedua, juga berada pada aliran Sungai Mangor tetapi pengelolaanya oleh Korong Sijangek dengan Korong Lubuk Punggai, Ketiga berada di Korong Lapau Jambu dan yang terakhir di Korong tungka. 
Berikut:

Berikut Data lokasi kawasan lauak baniek yang terdapat di Nagari Sugai Durian sebagai

Tabel 1 Data Lokasi Lauak Baniek di Nagari Sungai Durian

\begin{tabular}{lllc} 
No. & \multicolumn{1}{c}{ Nama Korong } & Lokasi Sungai & Panjang kawasan Lauak Baniek \\
\hline 1. & Sungai Durian & Batang Mangor & $2 \mathrm{~km}$ \\
\hline 2. & Sijangek & Batang Mangor & $1,5 \mathrm{~km}$ \\
\hline 3. & Lapau Jambu & Tikatiak. & $1 \mathrm{~km}$ \\
\hline 4. & Tungga & Tikatiak. & $1 \mathrm{~km}$ \\
\hline
\end{tabular}

Sumber: Observasi Peneliti di Nagari Sungai Durian

Tempat pemeliharaan lauak baniek ini dibatasi dengan bendera yang berwarna putih di bagian batas atas dan batas bawah lokasi ikan yang dilarang untuk ditangkap, yang digunakan sebagai tanda bahwa ikan di kawasan tersebut tidak boleh untuk ditangkap. Tempat ini dipilih masyarakat karena letaknya yang tidak jauh dari pemukiman masyarakat. Kemudian aliran sungai yang pilih ini juga ditentukan berdasarkan kontur lokasinya yang berbatu-batu serta balubuak ini dimungkinkan sebagai tempat persembunyian ikan-ikan jika terjadi banjir ataupun sungai agak surut. Pemilihan tempat ini juga mengakibatkan ikan tidak akan berkurang, ketika air sungai besar ikan akan hanyut mengikuti aliran sungai dan ketika air sungai kecil maka ikan akan mencari aliran sungai yang tidak dangkal.

Adapun jenis ikan yang terdapat adalah ikan Gariang (Tor sp). Ikan Kulari (Lobochilus sp), ikan Nila (Oreochromis Niloticus), ikan Gabus (Channa Striata), ikan Betok atau puyu (Anabas testudineus), ikan Nawi dan lain-lainnya. Setelah dalam jangka waktu pelarangan menangkap ikan habis maka ikan diizinkan untuk diambil dangan diadakan lomba mancing dengan kewajiban membayar insert bagi peserta yang ikut memancing dan bahkan pendapatan dari tahun 2000 - 2015 pernah mencapai pendapatan sebesar Rp 15.000.000, s/d Rp. 20.000.000,- dalam sekali pembongkaran.

Perolehan yang didapat dalam pembongkarang ikan ini dari tahun 2000 -2004 sepenuhnya dipergunakan untuk pembangunan masjid namun setelah tahun 2008 dana yang diperoleh tidak hanya untuk masjid saja tetapi juga digunakan untuk kebutuhan lain di Nagari Sungai Durian.

Fokus dalam penelitian ini adalahkearifan lokal lauak baniek 'pada masyarakat nagari Sungai Durian dalam pemanfaatan sumber daya lokal bagi pembangunan nagari. Seperti yang diungkapkan Adri Gusrianto dalam penelitian bahwa pemanfaatan lauak baniek pada dahulunya hanya dimanfaatkan untuk pembangunan masjid, sehingga seiring perkembangan waktu dan perkembangan pengelolaan mulai dari pemerintah nagari sampai pemerintahan desa dan kembali ke pemerintahan nagari di era pemerintahan Orde Baru, tentu pemanfaatannya juga mengalami perubahan (Gusrianto, 2016).

Penelitian ini dianalisis dengan teori Budaya Michael R. Dove. Budaya tradisional sangat dan selalu berkait dengan proses pembangunan dimana budaya tradisional tersebut melekat. Dove menunjukkan bahwa budaya tradisional tidak harus selalu ditafsirkan sebagai faktor penghambat pembangunan.Dalam penelitiannya Dove mengkategorikan empat kelompok yang bermanfaat terhadap pembangunan yaitu agama tradisional (ideologi), ekonomi, lingkungan hidup, dan perubahan sosial.Keempat aspek tersebut memberikan manfaat fungsional bagi masyarakat yang menganut sistem tradisional tersebut.Bahkan dalam batas-batas tertentu, budaya tradisional dilihat dapat berperan positif untuk mendorong laju moderenisasi.

\section{Metode Penelitian}

Penelitian ini dilakukan di Nagari Sungai Durian Kabupaten Padang Pariaman selama kurang lebih 2 bulan yaitu dari Oktober sampai November 2017. Dilihat dari segi pendekatannya, penelitian ini termasuk kualitatif dengan tipe etnografi. Pemilihan informan dilakukan secara purposive sampling dengan jumlah informan dua puluh orang. Data 
dikumpulkan melalui observasi partisipasi dan wawancara mendalam. Agar data yang diperoleh bisa dipercaya (absah), maka dalam penelitian ini dilakukan triangulasi yaitu triangulasi sumber.

Data yang diperoleh dianalisis dengan mengacu pada model analisis James P Spradley yaitu alur penelitian maju bertahap (Developmental Research Process) dengan langkah-langkah sebagai berikut: pertama yaitu menetapkan seorang informan, kemudian melakukan wawancara terhadap informan tersebut, setelah itu membuat catatan etnografis dan mengajukan pertanyaan deskriptif, setelah itu melakukan analisis wawancara etnografis, membuat analisis domain, mengajukan pertanyaan struktural, membuat analisis taksonomi, mengajukan pertanyaan kontras, membuat analisis komponen menentukan tema-tema budaya dan terakhir menulis etnografi (Spradley, 1997).

Dengan tahapan ini diharapkan dapat menghasilkan suatu deskriptif etnografis yang orisinil. Analisis data ini dapat dilakukan pada saat data awal ditetapkan yaitu sejak pertama kali peneliti turun kelapangan sampai berakhirnya penelitian

\section{Hasil dan Pembahasan}

\section{Sistem Pengelolaan Lauak Baniek}

Pengelolaan lauak baniek tidak dikelola seperti budidaya ikan pada umumnya tertapi hanya dibiarkan hidup bebas di sungai tanpa diganggu. Berdasarkan pengamatan peneliti di lapangan, peneliti juga melihat bahwasanya ikan yang terdapat di sungai hanya dibiarkan hidup bebas dan mencari makan sendiri, tanpa ada orang yang memberi makan ikan. Ikan-ikan hanya dijaga agar tidak diganggu dan ditangkap oleh masyarakat karena ikan sudah disepakati secara bersama untuk tidak diambil.

Pola pengelolaan lauak baniekyang terdapat di Nagari Sungai Durian jika diamati secara lebih dekat juga mengadopsi fungsi manajemen yang meliputi; Perencanaan, pengorganisasian, Pelaksanaan, dan pengawasan. Dalam pengelolaan Lauak Baniek terdapat langkah-langkah yang ditempuh dari awal pembentukan hingga dipenen. Setiap langkah yang diambil dalam proses pengelolaan lauak baniek diputuskan dengan cara musyawarah dan mufakat. Langkah-langkah tersebut adalah sebagai berikut:

\section{Perencanaan}

Dalam proses perencanaan pelaksanaan lauak baniek hal yang dilakukan adalah menentukan tujuan pelaksanaan lauak baniek yang akan dikelolah oleh masyarakat. Tujuantujuan ini tidak dirumuskan secara ekplisit melainkan harapan-harapan masyarakat dari pelaksanaan tersebut diantarannya: (1) Sebagai Sumber Pemasukan Nagari; Ide untuk mengelola ikan yang ada di sungai muncul karena kesadaran masyarakat terutama para pemimpin nagari melihat kondisi lingkungan terutama sungai sebagai salah satu sumber daya yang dapat dimanfaatkan sebagai pendapatan nagari, karena pada dasarnya Nagari Sungai Durian tidak memiliki aset nagari yang dapat dimanfaatkan sebagai sumber pemasukan nagari seperti pasar tradisional ataupun tempat-tempat wisata yang dapat dipungut retribusi. Sehingga timbulah ide pemanfaatan sungai sebagai salah satu sumberdaya yang dapat dimanfaatkan sebagai pendapatan nigari, (2) Sebagai Penunjang Ekonomi; Lauak baniek yang masyarakat kelola juga dapat memberikan dampak positif bagi perekonoian masyarakat setempat, karena dengan dilaksanakan kegiatan pembukaan lauak baniek maka akan menjadi tempat keramaian sehingga munculah dampak ekonomi bagi masyarakat dengan banyaknya warga masyarakat setempat yang berjualan, sehingga menjadi ekonomi musiman bagi warga, (3) Menjaga Kelestarian Sungai; Proses pengelolaan lauak baniek ini juga didasari oleh kesadaran masyarakat akan pentingnya menjaga kebersihan lingkungan terutama sungai, ini disebabkan karena sungai masih menjadi tempat yang strategis bagai masyarakat untuk membuang sampah sehingga karena adanya pengelolaan ikan di sungai menjadi perhatian bagi warga untuk melindungi ikan dari ancaman sampah yang dapat membahayakan ekosistem ikan, (4) Pelestarian Ikan; Lauak baniek merupakan bentuk pelarangan menangkap ikan disungai dalam jangka waktu tertentu. Sehingga ini akanmenjadi salah satu bentuk penjagaan ikan yang dapat meningkatkan populasi ikan

Culture \& Society: Journal of Anthropological Research Vol. 1, No. 3, Th. 2020 
sungai tersebut. Pelaksanaan lauak baniek ini juga atas dasar melihat kondisi ikan disungai yang sudah mulai berkurang karena penangkapan ikan yang tidak baik, seperti menggunankan racun dan menggunakan sengatan listrik.

Langkah selanjutnya yang dilakukan perencanaaan untuk mengelolah lauak baniek. Perencanaan dilakukan dengan proses musyawarah dan mufakat mulai dari menentukan lokasi tempat yang starategi untuk di lauak baniek, panjang kawasan lauak baniek yang tidak boleh melewati batas sungai tengga. Tiap-tiap batas sungai diberi tanda agar masyarakat tahu bahwa ikan yang ada di sungai tersebut merupakan lauak baniek. Kemudian menentukan batas waktu pemeliharaan ikan (lama pemeliharaan).

\section{Pengorganisasian}

Pengorganisasian mengarah kepada pembagian tugas agar suatu pengelolaan dapat berjalan dengan lancar dan mencapai tujuannya. Pada satu kelompok yang terdiri antara satu orang atau lebih ingin mencapai suatu tujuan yang sama, maka hubungan diantara mereka dapat menimbulkan masalah-masalah seperti siapa yang akan mengambil sebuah keputusan, siapa yang akan melaksanakan tindakan-tindakan yang telah direncanakan dan tindakan apa yang akan diambil pada suatu kondisi tertentu dan lainnya. Oleh karena itu perlu dilakukan suatu pengorganisasian agar tejadinya keharmonisan di dalam suatu kelompok sehingga mereka dapat bekerjasama dalam melaksanakan tugas-tugas tertentu guna mencapai tujuan yang sesuai dengan keinginan (Terry, 1986).

Di dalam pengelolaan lauak baniek yang terdapat di Nagari Sungai Durian, semua pihak perangkat nagari ambil bagian dalam pelaksanaannya. Pelaksanaanyaini merupakan kesepakatan pemuka adat nagari sehingga seluruh pihak dilibatkan baik itu, wali nagari, wali korong, ninik mamak, datuak, urang siak, pemuda dan masyarakat, semuanya berkumpul dan bermusyawarah untuk kesepakatan lauak baniek ini.

Dalam pelaksanaan lauak baniek ini terdapat alur koordinasi yang saling terkait antara satu dengan yang lain. Penglolaan terbesar diberikan tanggung jawab kepada pihak pemuda dan jika ikan menurut pemuda sudah layak di bongkar maka dapat mengusulkan kepada ketua pemuda dan ketua pemuda berkoordinasi dengan kapalo mudo dan setelah itu dibawa kepada forum yang lebih besar yaitu ninik mamak, datuak-datuak, urang siak nagaridantokoh masyarakat.

\section{Pelaksanaan}

Pelaksanaan ini merupakan implementasi dari proses perencanaan dan pengorganisasian. Pelaksanaan merupakan usaha untuk menggerakan anggota kelompok agar mereka berkeinginan dan berusaha mencapai tujuan. Pada lauak baniek ini, proses pelaksanaandapat jelas terlihat pada pelaksanaan pembukaan lauak baniek yang mana status yang miliki memaikan perannya dalam pelaksanaan.

Pembukaan lauak baniek dilakukan pada tanggal 18-19 November 2017, memang benar adanya bahwa tugas pelaksanaan berada pada pihak pemuda sebagai panitia pelaksana kegiatan pembukaan.Sebelum acara pembukaan lauak baniek, rapat dilaksanakan beberapat minggu sebelum acara penangkapan ikan yang ada di kawasan sungai lauak baniek.rapat dihadiri oleh pemimpin adat dan juga wali korong serta pemuda dan masyarakat. Pada saat pembukaan semua panitia yang telah terbentu bekerja sesuai dengan tugas yang telah ditentukan yaitu sesi ronda malam, sesi penjualan pening dan sesi pengawasan.

\section{Pengawasan}

Kebudayaan berperan dalam mengontrol tingkah laku masyarakat.Sebagai kontrol sosial terhadap masyarakat, kebudayaan berperan untuk mengembalikan tingkah laku masyarakat yang dianggap menyimpang ketingkah laku normal atau benar menurut adat.Kontrol sosial ini dapat dijalankan dalam bentuk sangksi restitutif atau represif.Sanksi restitutif ini adalh pemberian teguran atau pemberitahuan kepada anggota masyarakat yang tingkah lakunya dianggapmenyimpang, sehingga anggota masyarakat yang ditegur tersebut bahwa tingkah

Culture \& Society: Journal of Anthropological Research Vol. 1, No. 3, Th. 2020 
lakunya telah menyimpang dari perilaku yang dianggap normal.Sementara sanksi represif adalah tindakan setimpal yang diberikan kepada seseorang anggota masyarakat yang dianggap menyimpang, minsalnya dengan memberikan hukuman (Usman, 1994).

Salah satu bentuk pengawasan terhadap penjagaan lauak baniek adalah uduah. Meskipun uduah tidak digunakan lagi dalam pengelolaan lauak baniek tetapi orang merasa takut untuk mengambil karena takut terkena dampak buruk dari mencuri ikan, cerita ini terus-menerus diulang-ulang oleh masyarakat dan menceritakan kepada generasi penerus seperti anak-anak mereka sehingga menimbulkan rasa takut untuk mengambilnya.

Selain itu peran masyarakat dalam pengawasan sangat besar karena banyak aktivitas yang biasa dilakukan di sungai oleh masyarakat diantaranya mandi, mencuci pakaian dan mengambil air sebagai kebutuhan sehari-hari. Jika seseorang ketahuan mengambil ikan yang dilarang ini makan akan ada sanksi tertentu yang telah disepati masyarakat yang dikenakan pada pencuri tersebut. Hukuman yang pernah diterapkan pada orang yang ketahuan mencuri ikan larangan biasanya pertama dibawa terlebih dahulu ke kantor polisi yang biasanya hanya dititipkan sementara untuk diberi peringatan oleh pemuka adat Nagari serta di bantu pihak polisi, tetapi tidak akan diberi sanksi atau hukum per Undang-undangan karena memang hal ini tidak diatur dalam undang-undang. Kemudian sipencuri akan dikenakan sanksi adat berupa denda yang telah disepakiti yaitu 10 sak semen.

Selain itu jika ada masyarakat yang ketahuan menangkap ataupun memancing ikan pada lauak baniek makan akan mendapat teguran oleh masyarakat, namu jika masih tetap mengambil ikan pada sungai lauak baniek maka orang tersebut akan di tahlilkan oleh khatib di masjid pada hari Jum'at sebelum sholat Jum'at, agar orang tersebut dapat berubah menjadi baik.

\section{Lauak Baniek Sebagai Kearifan Lokal dalam Pemanfaatan Sumber Daya}

Lauak baniek pada masyarakat nagari sungai durian merupakan bentuk kearifan lokal masyarakat Sungai Durian dalam proses pengelolaan ikan yang ada di sungai. Pengelolaan ikan di sungai yang dilakukan secara komunal oleh masyarakat syarat akan pengetahuan lokal dan nilai-nilai yang dipelihara oleh masyarakat. Berikut nilai-nilai kearifan lokal masyarakat Sungai Durian yang terdapat dalam lauak baniek:

\section{Nilai Kearifan Lokal dalam Pelestarian Ikan}

Lauak baniek merupakan salah satu bentuk kesadaran masyarakat dalam melestarikan ikan sungai, karena selain bersifat melestarikan ikan juga mendatangkan pendapatan bagi nagari.Ikan yang dahulunya sebelum pelaksanaan lauak baniek sangat jarang ditemukan, sekarang ikan yang terdapat di sungai meningkat jumlah populasinya.Ini disebabkan karena ikan tidak diambil oleh masyarakat dalam jangka waktu yang cukup lama melainkan ikan dijaga bersama-sama oleh masyarakat sehingga ikan menjadi besar dan jumlahnya juga banyak.

Selain melestarikan ikan, proses pembukaan lauak baniek atau menangkap ikandapat dikatakan juga sebagai suatu bentuk kearifan. Hal ini disebabkan proses pembukaan yang dilakukan untuk mendapatkan ikan hanya dilakukan dengan cara dipancing menggunakan kail, tidak dengan menggunakan pukat atau jaring, tidak dengan racun ataupun dengan sengatan listrik. Sehingga ikan-ikan yang terpancing atau yang tertangkap hanyalah ikan-ikan yang berukuran sedang sampai ukuran besar, tidak ikan yang ukuran kecil, sehingga ikan masih dapat berkembang biak.

\section{Nilai Kearifan Lokal dalam Pelestarian Sungai}

Sungai pada masyarakat nagari Sungai Durian juga merupkan hak ulayat yang diperuntukan untuk masyarakat umum nagari, yang digunakna sebagai sumber ekonomi dan dimanfaatkan untuk kesejahteraan dan kemakmuran anak nagari dengan memperhatikan kelestarian alam dan dicadangkan untuk generasi yang akan datang. Sungai yang ada tidak secara langsung bebas diekploitasi potensinya oleh masyarakat, tetapi dikelolah secara komunal (bersama) agar dapat dimanfaatkan potensi yang ada secara maksimal. 
Pengelolaan lauak baniek ini merupakan salah satu bentuk kesadaran masyarakat dalam menjaga kelestarian lingkungan mereka, baik pelestarian sungai maupun pelestarian ikan yang terdapat di sungai. Menurut masyarakat setempat ketika ikan yang terdapat di sungai dijaga dan dipelihara, maka jumlah ikan akansemakin banyak, ketika ikan semakin banyak di sungai maka sungai akan bersih.

Lauak baniek yang dikelolah, masyarakat memahami dan mengetahui manfaat yang baik terhadap lingkungan sungai mereka, hal ini disebabkan ketika jumlah ikan yang terdapat dalam sungai meningkat maka menurut masyarakat air pada sungai akan bersih karena jumlah ikan yang banyak akan memakan kotoran-kotoran yang banyak pula dalam sungai sehingga menyebabkan sungai bersih.

Dampak positif lainlauak baniek ini terhadap sungai adalah dengan adanya pelarangan ikan ini, otomatis secara bersama masyarakat menjaga ikan yang ada agar dapat hidup sehat. Sehingga secara tidak langsung masyarakat tidak akan membuang sampah ke sungai atau mengotori sungai karena akan dapat menggangu kesehatan dan pertumbuhan ikan. Meskipun pelarangan membuang sampah ke sungai tidak diatur dalam kesepakatan masyarakat nagari akan tetapi masyarakat menyadari bahwa membuang sampah kesungai dapat menyebabkan sungai tercemar, sehingga jika sungai tercemar maka akan berdampak pada ikan.

\section{Nilai Kearifan Lokal dalam Bentuk Kerja Sama dan Wujud Persatuan Masyarakat}

Pengelolaan lauak baniek yang terdapat pada Nagari Sungai Durian mengandung nilai kerja sama antara elemen masyarakat dan juga merupakan wujud persatuan masyarakat nagari Sungai Durian. Nilai kerja sama yang terkandung dalan lauak baniek, tergambar dari proses pembukaan lauak baniek yang membutuhkan peran seluruh pihak yang terdapat dalam nagari. Karena pembukaan lauak baniek merupakan alek nagari yang mengatas nama kan nagari sebagai pihak penyelenggara kegiatan lomba mancing sehingga kerja sama merupakan bentuk nyata dari kesuksesan pembukaan lauak baniek.

pelaksanaanlauak baniek juga merupakan wujud kerja sama dan persatuan yang terjalin oleh pemuka adat nagari seperti ninik mamak, alim ulama, datuak cadiak pandai, wali korong, elemen pemuda serta masyarakat setempat. Dalam setiap status yang dimiliki memiliki perannya masing-masing dalam pelaksanaan lauak baniek. Meskipun pelaksanaan terbesar diserahkan sepenuhnya kepada pemuda sebagai inisiator pelaksanaannya.

Pengelolaan lauak baniek di nagari Sungai Durian dilakukan atas dasar kesepatan atau musyawarah seluruh pihak dan elemen masyarakat dalam nagari. Kesepakatan akan muncul jika adanya suatu kesamaan pendapat yang menciptakan sebuah keputusan. Keputusan lauak baniek tidak akan muncul jika diantara elemen masyarakat yang bersangkutan tidak terjalin kesatuan dan kesamaan pendapat. Selama pelaksanaan lauak baniek mulai dari tahun 2000 sampai pada tahun 2007 ini. Ada beberapa kali pelaksanaan lauak baniek yang tidak dilaksanaakan yaitu pada tahun 2004 sampai tahun 2006 dimana ada ketidak sepakatan diantara pemuka adat nagari mengenai pelaksanaan pembukaan lauak baniek pada saat itu. Ketidak sepakatan muncul dari pada urang siak nagari seperti alim ulama dan pihak pengurus masjid karena alasan pembukaan lauak baniek pada tahun 2004 menggunakan sistem inser oleh para peserta dan juga hasil dari danalauak baniek pada saat itu juga dibagi dengan pihak pemuda yang akan digunakan untuk keperluan pemuda. Sehingga karena tidak menemukan kesepakatan sehingga pada tahun 2004-2006 lauak baniek tidak dilaksanakan pengelolaannya.

Hal ini menunjukan bahwa lauak baniek di Nagari Sungai Durian merupakan salah satu wujud persatuan dalam masyarakat nagari Sungai Durian

\section{Lauak Baniek dalam Mendukung Pembangunan Nagari}

Penggunaan dana hasil dari lauak baniek pada masyarakat Nagari Sungai Durian sepenuhnya digunakan untuk kepentingan masyarakat Sungai Durian. Dana yang diperoleh tersebut digunakan untuk pembangunan nagari yang tidak masuk dalam program pembangunan oleh pemerintahan Nagari Sungai Durian.Pembangunan tersebut meliputi pembangunan fisik

Culture \& Society: Journal of Anthropological Research Vol. 1, No. 3, Th. 2020 
dan pembangunan non fisik. Pembangunan fisik yang dilakukan di Nagari Sungai Durian diantaranya seperti: pembangunan masjid, pembangunan Surau, pembangunan Posko pemuda, pembelian lampu penerangan jalan, pemeliharaan lapangan oleh raga serta kebutuhankebutuhan laian seperti pembelian kursi untuk kegiatan nagari. Sedangan pembangunan bersifat non-fisik dari lauak baniek yaitu seperti digunakan untuk kegiatan keagamaan serta dapat meningkatkan perekonomian masyarakat.

\section{Pembangunan Fisik}

Adapun pembangunan yang telah dilakukan pada Nagari sungai Durian dengan memanfaatkan danalauak baniek adalah sebagai berikut:

\section{Pembangunan Masjid}

Sebagaimana sejarah awal mulanya pembentukan pengelolaan lauak baniek memang berlandaskan kepada tujuan untuk pembangunan, yaitu pembangunan masjid di Nagari Sungai Durian yang saat ini bernama Masjid Raya Nagari Sungai Durian. Melihat sejarah awal mula ceritanya bahwa ketika akan melaksanakan pembangunan masjid, tentu membutuhkan dana yang tidak sedikit, sehingga karena keterbatasan dana dalam pembangunan sehingga pembangunan masjid pada waktu itu terbengkalai. Sehingga munculah sebuah keputusan dari hasil musyawarah pemuka adat, untuk memanfaatkan sumber daya alam yang terdapat di nagari yaitu pemanfaatan sungai sebagai kawasan ikan laragan yang hasil dari perolehan ikan, akan dimanfaatkan sepenuhnya untuk keperluan masjid.

Dana yang diperoleh pada pembukaan lauak baniek tahun ini, yang dibuka pada tanggal 18-19 November 2017 berhasil menghasilkan dana sebesar Rp. 15.000.000. dana ini dikeluarkan dana yang dihabiskan untuk keperluan pelaksanaan sebesar Rp. 3.000.000. kemudian dari dana sisa diserahkan untuk masjid sebesar Rp. 6.000.000. dan sisinya Rp.6.000.000. diserahkan untuk masjid Raya Sungai Durian. Dana hasil perolehan dari pengelolaan lauak baniek yang diserahkan kepada pengurus masjid, dimasukan kedalam kas masjid. Uang ditelah diserahkan kepada pihak masjid akan digunakan untuk keperluan masjid seperti sarana-sarana penunjang yang diperlukan untuk mendukung ibadah yang dilakukan di dalam masjid.

\section{Pembangunan Surau}

Penggunaan dana lauak baniek juga digunakan untuk pembangunan masjid yang terdapat di Nagari sungai Durian, akan tetapi surau yang dibangun dengan dana ini tidak semua surau yang terdapat di Nagari Sungai Durian, karena begitu banyak surau-surau yang terdapat di nagari Sungai Durian, tercatat ada sekitar 20 buah surau yang terdapat di Nagari Sungai Durian yang kebanyakan surau merupakan surau- surau kaum atau suku-suku yang terdapat di Nagari Sungai Durian. Sehingga jika dana dari lauak baniek digunakan semuanya untuk membangun surau maka dana tersebut tidak akan cukup. Selain itu jika dana di bagi kepada masing-masing surau ditakutkan akan terjadi kecemburuan pada masing-masing suku pemilik surau karena ditakutkan pem bagiannya tidak adil atau merata.

Pengelolaan lauak baniek ini merupakan tanggung jawab masing-masing korong yang terdapat di Nagari Sungai Durian sehingga penggunaanya pun diserahkan pula kepada masingmasing korong. Sehingga hanya korong tertentu yang memanfaatkannya untuk kepentingan surau, seperti korong Lapau Jambu yang memberikan dana dari hasil lauak banieknya untuk surau yang terdapat di korongnya. Karena memang benar berdasarkan pengamatan peneliti di korong Lapau Jambu tidak terdapat masjid hanya terdapat 2 buah surau, sehingga dana tersebut dilimpahkan ke surau yang ada. Selain itu di korong Lapau Jambu juga tercatat hanya terdapat 2 unit surau, sehingga untuk membagi dana tidaklah terlalu sulit. Hal ini berbeda dengan korongkorong yang lain yang memiliki jumlah surau yang banyak, seperti di korong Sungai Durian terdapat 9 Buah Surau, Korong Sijangek 5 buah Surau dan Korong Tungka 4 buah surau.

Penggunaan danalauak baniek yang digunakan untuk membangun surau di Nagari Sungai Durian hanya terdapat di korong Lapau Jambu. Surau yang dibangun adalah Surau Ar-Rahmah atau Surau Polong surau ini berada di Korong Tungka.Lauak baniek pada Korong Lapau Jambu 
terakhir dibuka bulan Agustus 2017.Dana yang diperoleh pada pembukaan ini sekitar Rp. 5.000.000.dan seluruhnya dilimpahkan kepada kepentingan Surau Polong setelah dikeluarkan dana yang terpakai untuk pelaksanaan pembukaan lauak baniek.

\section{Pembangunan Posko Pemuda Nagari Sungai Durian}

Penggunaan danalauak baniek pada Korong Sungai Durian juga digunakan untuk pembangunan posko pemuda yang ada di nagari. Dana yang digunakan untuk melakukan pembangunan posko pemuda merupakan dana dari lauak baniek yang telah dilimpahkan kepada pihak pemuda sebagai panitia dan juga sebagai pengelolaan lauak baniek. pembangunan posko pemuda merupakan salah satu penggunaan dana dari dana lauak baniek karena posko merupakan salah satu simbol persatuan pemuda nagari, yang biasa digunakan oleh pemuda untuk berkumpul dan merencanakan apa yang dilakukan

\section{Pembelian Lampu Penerangan jalan Nagari Sungai Durian}

Penggunaan danalauak baniek juga dimanfaatkan oleh pemuda untuk meingkatkan kenyamanan dalam nagari, salah satunya yaitu digunakan untuk membeli lampu penerangan jalan yang akan dipasang pada setiap jalan-jalan gelap di Nagari Sungai Durian. Hal ini dilakukan karena di Nagari Sungai Durian masih tergolong daerah pedesaan, dimana lokasi rumah yang terdapat di nagari berpencar-pencar sehingga jalan-jalan dalam nagari menjadi gelap.

\section{Pemeliharaan Lapangan Olah Raga}

Nagari Sungai Duria adalah salah satu nagari yang aktif dalam kegiatan keolahragaan, ini dapat dilihat pada setiap korong pada Nagari Sungai Durianbanyak club-club olahraga diantaranya ada sepak bola, bulu tangkis dan juga sepak takraw.

Nagari Sungai Durian sangat aktif dalam cabang-cabang olahraga sehingga fasiitas penunjang untuk kegiatan tersebut diadakan oleh pihak pemuda, terlihat beberapa lapangan sepak bola, bulutangkis dan lapangan takraw. Akan tetapi setelah pemekaran Nagari Sungai Durian yang sebelumnya hanya sebuah korong dan sekarang berubah menjadi nagari, sehingga aset-aset seperti lapangan olahraga tentu berpidah alih kepada wilayah tempat lapangan tersebut berada sehingga yang tersisa di nagari Sungai Durian saat ini adalah hanya lapangan sepak bola yang berada di Korong Sijangek dan lapangan sepak takraw yang berada di Korong tungka sarta tempat perkemahan yang juga terdapat di Korong Sijangek.

Dalam penggunaan dana hasil lauak baniek yang masuk ke dalam dana kas pemuda juga digunakan untuk pemeliharaan lapangan oleh raga. seperti pembelian net atau jaring untuk gawang sepak bola dan net takraw

\section{Non Fisik}

Adapun bentuk pembangunan yang bersifat Non Fisik atau yang tidak terlihat namun bermafaat bagi masyarakat adalah sebagai berikut:

\section{Acara keagamaan}

Kegiatan keagamaan yang biasa dilakukan oleh masyarakat nagari Sungai Durian yaitu acara maulid Nabi Muhammad SAW atau yang biasa disebut mauluik. Peringatan Maulid Nabi diperingati setiap 12 Rabiul Awal penanggalan Hijriah.Ada berbagai acara yang dilakukan dalam memperingati lahirnya Nabi Muhammad SAW tersebut.

Biasanya acara Maulid Nabi dengan mengadakan pengajian-pengajian di surau-surau dan di masjid dan juga melakukan doa-doa yang dipimpin oleh urang Siak. Setiap masyarakat membuat lamang untuk diantar ke masjid atau kesurau-surautempat maulid nabi dilakukan sebanyak 2 batang lamang, yang terdiri satu batang lamang pulut dan satu batang lagi lamang pisang. Selain mengantar lamang masyarakat nagari juga membuat makanan yang berisi nasi dan lauk pauk yang nantinya akan dimakan bersama oleh urang siak dan jamaah yang hadir. Hasil dari dana lauak baniek yang dilimpahkan untuk masjid juga digunakan untuk acara maulid nabi di Nagari Sungai Durian. Karena acara maulid nabi merupakan salah satu alek nagari dan juga 
kegiatan agama yang pengangkatannya butuh kerja sama dan peran serta seluruh masyarakat nagari Sungai Durian, ada kegiatan makan bajamba di dalam masjid dimana ibuk-ibuk memasak secara bersama-sama untuk menghidangkan menu yang akan dimasak dan juga salah satu alasan pembukaan lauak baniek pada tahun ini adalah karena akan dilaksanakan acara maulid nabi ini yang membutuhkan dana dalam pelaksanaannya.

\section{Meningkatkan Ekonomi Masyarakat}

Pelaksanaan pembukaan lauak baniek ini tidak hanya berdampak pada pembangunan fisik semata, tetapi juga menghidupkan sektor perekonomian musiman masyarakat sekitar tempat pembukaan lauak baniek.hal ini disebabkan banyaknya orang-orang yang datang untuk menghadiri pembukaan lauak baniek ini, baik peserta yang ikut memancing maupun masyarakat sekitar yang ikut menyaksikan orang-orang memancing ikan di sungai.

Hal ini memang disebabkan oleh adanya kebutuhan dari para peserta yang datang ataupun dari masyarakat yang menonton untuk membeli kebutuhan seperti makanan ataupun minuman pada saat di lapangan, sehingga banyak masyarakat yang membuka kedai-kedai untuk berjualan makanan dan minuman disekitar sungai.

Bentuk usaha yang dilakukan masyarakat pada saat acara pembukaaan lauak baniek yang berada di korong Sungai Durian pada tanggal 18-19 November 2017 lalu yaitu berjualan dengan mendirikan tenda-tenda semi permanen. Yang mereka jual pada umumnya adalah makananmakanan seperti makanan untuk sarapan, nasi, sate, lontong dan makanan-makanan ringan.

Ini merupakan sebuah proses yang baik untuk kemajuan nagari karena lauak baniek bisa dimanfaatkan sebagai sumber ekonomi masyarakat walapun hanya bersifat musiman. Sudah ada sebuah rancangan dari pihak nagari untuk menjadikan kawasan sungai lauak baniek sebagai kawasan wisata ikan larangan, sehingga orang akan banyak datang untuk melihat ikan dan memberi makan ikan, sehingga ekonomi masyarakat sekitar juga bisa hidup.

\section{Analisis Lauak Baniek sebagai Pendukung Pembangunan Nagari}

Merujuk pada teori Budaya Lokal dan Pembangunan yang dipelopori oleh Michael R. Dove. Teori ini muncul berdasarkan hasil kajian dove yang hendak mencoba melihat interaksi antara kebijakan pembangunan di Indonesia dan aneka ragam budaya local yang terdapat di Indonesia. Dove dengan tidak ragu-ragu menyatakan, bahwa tradisional tidak berarti harus terbelakang. Menurutnya budaya tradisional sangat dan selalu terkait dengan proses perubahan ekonomi sosial dan politik dari masyarakat pada tempat budaya tradisional itu melekat, artinya dove berpendapat bahwa budaya tradisional sesalu mengalami perubahan yang dinamis, dan oleh karena itu budaya tradisional tidak mengganggu proses pembangunan.

Analisis peneliti melihat bahwa lauak baniek pada masyarakat Nagari Sungai Durian merupakan salah satu bentuk dari budaya lokal dan budaya tradisional yang hidup dan berkembang ditengah-tengah masyarakat. Bagi masyarakat Sungai Durian keberadaan lauak baniek merupakan sebuah modal sosial bagi masyarakat untuk dapat mengambil manfaat dari sumber daya lokal yang mereka miliki.Pengelolaan ikan di sungai telah mendatangkan pendapatan bagi nagari mereka dan dapat digunakan sebagai sumber pembangunan nagari. Hal ini terlihat dalam proses pengelolaan ikan yang dilarang untuk ditangkap pada sungai, sehingga ikan menjadi banyak dan dapat mendatangkan pendapatan yang besar bagi nagari dan digunakan untuk kebutuhan umum masyarakat nagari.

Dalam kajian Dove menyatakan bahwa budaya tradisional sangat dan selalu berkait dengan proses pembangunan ekonomi, sosial dan politik dimana budaya tradisional tersebut melekat. Dalam penelitiannya Dove mengkategorikan empat kelompok yang bermanfaat terhadap pembangunan yaitu agama tradisional (ideologi), ekonomi, lingkungan hidup, dan perubahan sosial. Keempat aspek tersebut memberikan manfaat fungsional bagi masyarakat yang menganut sistem tradisional tersebut.

Keempat kelompok tersebut terdapat dalam lauak baniek, yang mana karna faktor agama munculah lauak baniek, hal ini dilandasi karena keinginan untuk membangun masjid tempat

Culture \& Society: Journal of Anthropological Research Vol. 1, No. 3, Th. 2020 
ibadah mereka. Faktor ekonomi, hal ini dimaksudkan bahwa ikan yang masyarakat pelihar di sungai merupakan salah satu yang dapat berperan dalam menununjang perekonomian. ketiga faktor lingkungan hidup yaitu pemanfaatan sungai oleh masyarakat karena merupakan salah satu sumber daya lokal yang masyarakat miliki sehingga dapat dimanfaatkan untuk pembangunan dan yang terakhir terkait dengan perubahan sosial artinya adanya suatu proses perkembangan dari waktu-kewaktu yang dapat kita lihat bahwa pemanfaatanya yang pada awalnya hanya untuk kepentingan agama dan seiring dengan perkembangan nagari bahwa pemuda juga menjadi perhatian sehingga penggunaan dana juga digunakan untuk kebutuhan pemuda nagari.

\section{Kesimpulan}

Dari hasil penelitian dapat dinyatakan bahwa lauak baniek yang terdapat di Nagari Sungai Durian merupakan salah satu usaha pemanfaataan sumber daya ikan yang ada di sungai yang dimiliki masyarakat.Lauak baniek diartikan sebagai "Ikan Berniat" dimana kata "lauak"berarti "ikan" dan kata "baniek" yang artinya "berniat", jadi secara sederhana lauak baniek dapat diartikan sebagai ikan yang sudah diniatkan dalam artian secara ikan yang terdapat di sungai secara sepakat masyarakat tidak boleh mengambil ikan tersebut karena sudah diniatkan untuk kepentingan bersama. Pengelolahan lauak baniek dilakukan secara komunal (bersama) oleh masyarakat atau yang biasa disebut (Community Based Fisheries Management) yang merupkan salah satu pendekatan pengelolaan sumber daya alam yang meletakan pengetahuan dan kesadaran lingkungan masyarakat lokal sebagai dasar pengelolaannya.

Pengelolaan lauak baniek yang selama ini hidup dan laksanakan oleh masyarakat setempat terdapat nilai-nilai kearifan lokal yang memiliki dampak positif. Mulai dari proses pelarangan untuk menangkap ikan hingga proses pembukaan semuanya memiliki nilai yang baik, tidak hanya untuk masyarakat setempat tetapi juga dampak yang baik terhadap kelangsungan dan kelestarian lingkungannya yaitu (1) nilai pelestarian terhadap ikan, karena ikan dijaga dan dibiarkan hidup berkembang biak di sungai sehingga bernilai baik terhadap kelestarian ikan, kemudian (2) memiliki nilai positif terhadap pelestarian sungai karena ikan yang terdapat di sungai tidak hanya dilarang untuk ditangkap tetapi juga dilindungi agar ikan dapat hidup baik seperti tidak buang sampah kedalam sungai yang dapat mengakibatkan pencemaran air sehingga dengan adanya lauak baniek hal demikian dapat diminimalisir dan (3) memiliki nilai kerja sama dan wujud persatuan dalam masyarakat Nagari Sungai Durian, karena proses pembukaan lauak baniek merupakan alek nagari yang membutuhkan peran serta semua pihak sehingga kerjasama dan persatuan diatara masyarakat, pemuda dan tokoh adat menjadi penting adanya.

\section{Daftar Pustaka}

Bagong, Suyanto \& Sutinah. (2005). Metode Penelitian Sosial Berbagai Alternatif Pendekatan. Jakarta: Kencana

Bungin, B. (2012). Metodologi Penelitian Kualitatif. Jakarta: Raja Garafindo Persada.

Gusrianto, A. (2016). Ikan Larangan di Kabupaten Padang Pariaman: Sejarah Pengelolaan Dari pemerintah Desa ke Pemerintah Nagari 1979-2013. Skripsi. Universitas Negeri Padang

Putra, A. (1985). Etnosains dan Etnometodologi: Sebuah Perbandingan. Jakarta: LIPI.

Suwarsono \& Alvin Y. (1991). Perubahan Sosial dan Pembangunan di Indonesia. Jakarta LP3ES.

Spradley, J. (1997). Metode Etnografi. Yogyakarta: Tiara Wacana

Suwarsono, S \& Alvin, Y. (1991). Perubahan Sosial dan Pembangunan di Indonesia. Jakarta LP3ES.

Terry, G. (1986). Asas-asas Manajemen alih bahasa oleh Winardi. Bandung: Alumni

Usman, P. (1994). Teori-Teori Sosial Budaya, Jakarta: Dirjen Dikti

Usman, P. (2005). Kearifan Lokal dalam Pengelolaan SDA (kekayaan Nagari menatap Masa Depan). Padang: LBH Padang 